\title{
Challenges Facing Micro and Small Enterprises in Inventory Management in Kisii Town, Kenya
}

\author{
Fred Ongisa Nyang'au, \\ Jomo Kenyatta University of Agriculture and Technology -Kenya
}

\begin{abstract}
This study focused on the challenges facing micro and small enterprises (MSEs) in inventory management in Kisii Town, Kenya. The objective of the study was to evaluate the challenges facing MSEs in inventory management in Kisii Town-Kenya. Some of the inventory management challenges include demand variability, material handling, inventory costs, inadequate information and stock setting. The accessible population was the three hundred and eight (308) registered MSEs in Kisii Town. The study used stratified random sampling to group the businesses into homogeneous entities. A random sample was then drawn from the each group. Questionnaire with both open and closed items used to obtain data. Correlation analyses were used to ascertain the relationship between inventory challenges and effective inventory management in MSEs. The study established the existence of a strong negative relationship between demand variability, inadequate information sharing and inventory costs and inventory management.
\end{abstract}

Key Words: challenges, forecast, inventory, lead time, micro and small enterprises and stock out

\section{Introduction}

This study was on the challenges micro and small enterprises (MSEs) face in inventory management. Getting a universally acceptable definition of MSE has been challenging. However, some features have been used variously to define these entities. These characteristics are the number of employees, the amount of initial capital investment, the value of assets, the size of the business premises and annual turn over (Hamisi, 2010; Kauffmann, 2005; Bowen et al.2009). According to Association of Enterprise Opportunity (AEO), a microenterprise is a type of small business with less than 5 employees and a seed capital of less than US \$35 000. In addition, various journals report that for developed countries, micro and small enterprises (MSEs) are those business entities with no more than 100 employees. It further reports that United States adopted micro and small enterprises from the developing countries with a view to attaining social justice for the marginalized. Currently MSEs represent the smallest business entities in the developed nations.

In Kenya, although micro and small enterprises existed before, they gained prominence in the 1990s largely because the World Bank and the International Monetary Fund advocated for structural adjustment programs (SAPs). The programs encouraged liberalization and privatization of the country's economy; consequently, massive job losses. The terminal benefits were invested in informal businesses which proved a big success in job and wealth creation (House, 2009; Prasad et al. 2010; Chu et al. 2007). The 1999 Kenya National Micro and Small Enterprises Baseline Survey established that MSEs contributed about 18.4\% of the country's Gross Domestic Product (GDP) because 74.2\% of jobs were in the MSE subsector. Kenya (1999) defined micro, small and medium enterprises (MSMEs) as those in any business in the private sector which employ not more than 50 employees.

Micro, Small and Medium Enterprises Act [MSME], 2013 adopts two metrics to define non manufacturing and production MSEs: the number of employees and the annual sales volume. Those enterprises with an annual turn over of less than US $\$ 60000$ and employees not exceeding 50 can be described as micro and small enterprises. Although a universal working definition of MSE has not been achieved, these businesses show universal characteristics (Hatten, 2012; Mbithi and Mainga, 2006; Sandu [1997, cited in Lobontieu, 2001). Micro and small businesses;

a) Are often owner- managed with few employees,

b) Are labour intensive because of low absorption of technology,

c) Have unpredictable cash flows and uncontrolled costs,

d) Are flexible, and

e) May advance to more sustainable businesses.

It is worth noting that since the initiation of Millennium Development Goals, commonly known as MDGs, and the Kenya Vision 2030, the government has attempted to support MSEs through various pieces of legislation such as Investment Promotion Act, 2004; Public Procurement and Disposal Act, 2006 and Micro, Small and Medium Enterprises Bill, 2009 (Mbithi and Mainga, 2006). Towards this end, MSEs are expected to continue playing vital economic role especially in new job and wealth creation. According to Kenya Economic Survey 2011, MSEs contributed $80.6 \%$ of new jobs and accounted for $18 \%$ of the Gross Domestic Product (GDP). The 
successful implementation of the Economic Recovery Strategy for Wealth and Employment Creation which saw the country grow economically from $0.6 \%$ in 2002 to $6.1 \%$ GDP in 2006 hinged on MSEs (Kenya, 2005). This was because the government emphasized on poverty reduction through its Sessional Paper No. 2 of 2005 on Development of Micro and Small Enterprises for Wealth and Employment Creation for Poverty Reduction.

Evidence suggest that Kenya's economy consists of about 900000 MSEs in diverse fields such as mining, manufacturing, production services, distribution and retailing (Chu et al. 2007). Of these $50 \%$ are in retail and commerce while $30 \%$ participate in manufacturing and production service. Mbithi and Mainga (2006) indicated that the number of MSEs has over the years risen because of the availability of relatively cheap loans courtesy of Youth Development Fund, Women Enterprise Fund, microfinance institutions, faith-based organizations and other non-governmental organizations (NGOs).

From the foregoing discussion, it is clear that the government has created statutory environment to cushion against financial, legal and tax- related challenges. However some challenges are inherently difficult to legislate against because Kenya is a liberalized economy. These constraints include cut throat competition, unpredictable demand patterns, changing customer preferences and others (Bowen, Morara and Mureithi, 2009; Chopra, Meindl and Kalra, 2007). These challenges require businesses to respond to specific customer demands in order to have a competitive advantage. Thus, the role of supply chain (SC) and inventory management in gaining that advantage is recognized by (Gunisekaran and Ngai, 2004). This paper defines inventory management as planning, implementation, evaluation and control of any quantifiable items used, stored, sold or transported by a business organisation.

Inventory management is a major issue in SCM because it helps to eliminate wasteful and expensive inventory (Routroy and Kodali, 2005; Alande et al. 2004). Effective inventory management is critical to the successful management of MSEs. Robinson, Logan and Salem (1985) demonstrated that inadequate inventory planning has been one of the major causes of small business failure. Equally, inventory management policies are critical in determining the profitability of businesses, especially those whose inventory represents about $20 \%$ to $60 \%$ of their total assets (Arnold, 1998).

\subsection{Theoretical framework}

\section{Literature Review}

The two main inventory theories in inventory management are: inventory management theory which is also known as mathematical inventory theory and the theory of constraints. There are several mathematical models/ theories in inventory management depending on the predictability of demand (Heizer and Render, 2006). The two common models in scientific inventory theory are deterministic and stochastic inventory models. According to Morgenstern (2007), when demand in future can be determined through forecasting with some precision, deterministic model would be used to set inventory policy. Stochastic, on the other hand, is used where the demand in a given period is variable- cannot be predicted.

Theory of Constraints (TOC) is a management philosophy developed by Goldratt (1984) in his book, The Goal. It postulates that an organization is a system, and every system has at least one constraint limiting it from achieving its goal of making (more) money. In order to improve the performance of the system, these constraints must be identified (described) and corrective measures taken (a prescription). Identifying the constraints help to focus the limited resources to the weakest part for the system to improve. Fig. 1 shows the three ways to the ultimate goal: throughput (T), inventory (I) and operating expenses (OE). A system can, therefore, be evaluated and controlled by the three. Throughput is defined as the rate at which the system generates revenue through sales. Inventory is all the money that the system has invested in purchasing things which it intends to sell. Goldratt defined operational expense as all the money the system spends to change inventory into throughput.

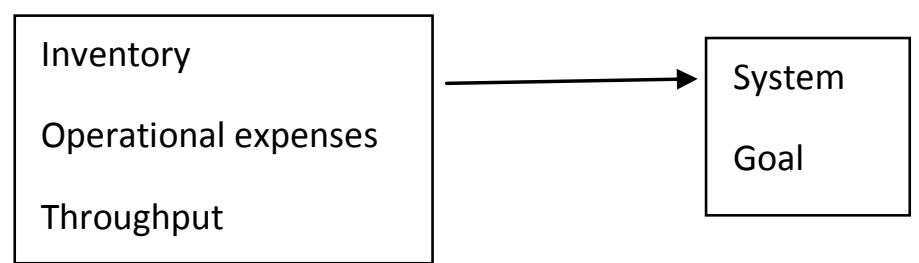

FIGURE 1: Three ways to the ultimate system goal

A constraint is anything that prevents a system from achieving its goal. The theorist suggests two types of constraints: internal and external constraints. An internal constraint exists when a system cannot produce/deliver enough for the market while an external one exists when the system delivers/produces more than the market can take. Internal constraints could be physical or policy constraints. From Goldratt's three measurement 
dimensions, an organization has three different ways of improving the organizational output: increasing the $\mathrm{T}$, reducing the I or reducing the $\mathrm{OE}$. This research is concerned with inventory as constraint that can be focused on to cause system improvement. The approach uses certain parameters to ensure appropriate levels of inventory. These parameters are: a) inventory is held as close as possible to the demand and source to ensure quick shipping of goods. b) Upper limits of stock are kept by having buffer inventory. c) Quick placement of orders whenever inventories decrease d) buffer inventory should always be adjusted to reflect changes in the rates of demand.

There are constraints that complicate successful inventory management: uncertain demand, costs lead times, production prices etc (Gunus and Guneri, 2007). Underlying this research is the belief that inventory management in MSEs is faced with some challenges such as escalating inventory costs, untrained personnel, inaccurate record keeping and demand variability.

\subsubsection{Inventory costs on inventory management}

This study assumed that determination, location and control of costs related to inventory are a major challenge facing effective and efficient inventory management. Sople (2010) indicated that a lot of working capital is tied in inventory. Similarly, Chase et al (2009) showed that inventory control is vital as it holds up money. Calculating and balancing costs of inventory with appropriate level of responsiveness is very difficult so companies tend to limit costs. This cost containment may lead to low service levels thereby compromising on the competitive ability of an organization.

Inventory costs could emanate from holding costs, costs of stock outs, acquisition costs. First, acquisition costs: acquisition costs include preliminary costs for preparing requisition, vendor selection, negotiation costs; placement costs such as order preparation, stationery costs and post-placement costs which include receipt of goods, material handling, inspection and payment of invoices. Secondly, holding costs are storage costs-space, rates, light, heat and power costs; labour costs that relate to handling, clerical and inspection; cost of insurance; interest on capital tied up; costs of deterioration, obsolescence and pilferage. Other costs relate to stock outs: costs associated with lack of inventory. These costs are; loss of production output, costs of idle time, loss of customer goodwill and costs of rectifying the stock out.

\subsubsection{Demand variability on inventory management}

It was also assumed that change in demand or demand distortion directly affects the management of inventory. According to Tersine (1982), the demand variations affect inventory levels and costs and ultimately the profits. When demand forecast is about low demand but the demand is high, stock outs will be realized therefore compromising on customer responsiveness (Hamisi, 2010). Inversely, high stock levels during low demand period results in high inventory costs. Demand distortion is basically due to inaccurate information on supplies, inaccurate demand forecasts, batch ordering, price variations and promotions which stimulate forward buying (stock up). Lack of coordination among supply chain members through information sharing creates demand variation throughout the supply chain. This is often referred to as a bullwhip effect. Generally, high demand variability leads to deterioration of inventory management and performance.

\subsubsection{Inadequate information-sharing on inventory management}

Chopra et al. (2007: 600) stated that "The lack of information sharing between stages of the supply chain magnifies the bullwhip effect." Accurate information on orders, stock levels and customer feedback is vital in decision-making. In addition, Hamisi (2010) indicated that information flows allow the various partners to coordinate both their long-term and short-term plans. This therefore means that inadequate informationsharing among the supply chain network members on the demand patterns, anticipated shortages, price variations and government policies was assumed to create a major challenge in the management of inventory. Information-sharing is the key to supply chain coordination and integration which maximizes supply chain profitability through cost containment and responsiveness. Effective inventory management depends heavily on accurate information sharing on stock levels, shipment, customer preferences and costs across suppliers, manufacturers, distributors, wholesalers, retailers and customers. The study assumes that MSEs rely on information from both their suppliers and customers to make decisions on what to stock and levels of stock to hold. Since most MSEs deal in variety of SKUs from different suppliers, the information flow and management is erratic and uncoordinated. Hence, a challenge to the MSEs inventory management.

\subsubsection{Stock levels and inventory management}

Sople (2010) stated that appropriate levels of stock are necessary to ensure high levels of customer services. However, there need to be a trade -off between inventory levels and customer responsiveness since the higher the inventory level the higher the costs. According to Chopra et al. (2007) stock levels include cycle inventory and safety inventory carried to satisfy demand for a period. Organisations set replenishment policies 
regarding when and how much to reorder depending on uncertainty of both demand and supply and level of service desired. The replenishment policy could either be continuous or periodic review. A continuous replenishment review involves tracking the inventory continuously so as to place an order whenever the stock declines to predetermined reorder point (Baily et al. 2005). When firms check their stock at regular periodic intervals to raise stock to desired levels, they are engaged in periodic replenishment policy. The study was of the assumption that MSEs face challenges in setting stock levels due to demand and supply uncertainty and the subsequent need of trade off between stock levels and customer service.

\subsubsection{Inventory management}

According to Chopra et al. (2007) and Sople (2010) inventory exist in businesses because of a mismatch between demand and supply. Inventory could be in form of raw materials, work-in-progress or finished products. Inventory is therefore important in anticipating future demand and avoiding lost sales. However, the critical decisions in inventory control are when to order and how much to order so as to meet customer requirements, working capital requirements and profitability. Ideally inventory management is about reduced inventory levels, reduced costs, improved customer service levels, improved operations and improved profitability (Hatten, 2012; Christopher, 1992; Hamisi, 2010; Sople, 2010; Chopra et al. 2007).

\subsection{Research Design}

\section{Research Methods}

The research used quantitative approach, survey design. The study intended to evaluate the challenges that face small businesses. Such issues are best investigated through descriptive survey (Bougie and Sekaran, 2009; Robson, 2002; Mugenda and Mugenda 1999). In addition, according to Saunders et al. (2009), the survey strategy tends to be important in descriptive and exploratory research because it can collect a large amount of data from a sizeable population in an economical way. This design entails description of the affairs as they exist at the present. The design therefore enables the researcher to establish the relationship between variables.

\subsection{Target Population}

The study targeted all small businesses in Kenya. The accessible population was the 308 registered small businesses in Kisii Town (TABLE 1). The population was chosen because it has all the types of businesses: hardware stores, pharmacies, consumer goods retail stores, bars and restaurants. The population was therefore appropriate for the study on inventory management. The accessible population was categorized as follows:

TABLE1: Types of small businesses in Kisii Town (accessible population)

\begin{tabular}{ll}
\hline Types of small businesses & Number \\
\hline Hardware stores & 20 \\
\hline Consumer goods retail store & 183 \\
\hline Bars and restaurants & 54 \\
\hline Pharmacies & 15 \\
\hline Electronic shops & 26 \\
\hline Bookshops & 10 \\
\hline TotalMSEs & 308 \\
\hline
\end{tabular}

\subsection{Sampling techniques}

The study used stratified random sampling. Stratified random sampling involves dividing the accessible population (308 small businesses with a total of 308 respondents) into homogenous subgroups and then taking a simple random in each subgroup. Saunders et al. (2009) argue that dividing the population into series of relevant strata means that the sample is more likely to be representative as one can ensure proportional representation within the sample. Mugenda and Mugenda (1999) point out that both these sampling techniques are useful in collecting focused information and that they save time.

\subsubsection{Sampling of businesses}

The researcher used stratified random sampling to pick 62 respondents who represent $20 \%$ of the 308 . According to Mugenda and Mugenda (1999) for descriptive studies, $10 \%$ of the accessible population is enough. This research sampled $20 \%$ of the accessible population because the population was broken into sub-groups. The bigger sample for this research design minimized the sampling error. TABLE 2 summarises the sample distribution for the micro and small businesses. 
TABLE 2: Sample distribution for small businesses

\begin{tabular}{lll}
\hline Types of micro and small enterprises & Number & Samples \\
\hline Hardware stores & 20 & 4 \\
\hline Consumer goods retail stores & 183 & 37 \\
\hline Bars and restaurants & 54 & 11 \\
\hline Pharmacies & 15 & 3 \\
\hline Electronic shops & 26 & 5 \\
\hline Bookshops & 10 & 2 \\
\hline Total MSEs & 308 & 62 \\
& & \\
\hline
\end{tabular}

\subsection{Data collection}

\subsubsection{Data collection instrument}

This study used semi-structured questionnaires to collect information. This selection was informed by the nature of information to be collected and the objective of the study which was to examine the challenges facing micro and small businesses in effective inventory management. Such information is best collected by questionnaires (Mugenda and Mugenda, 1999; Saunders et al. 2009).

The researcher used semi- structured questionnaires. The use of this instrument involves asking both structured and open-ended questions. This method enabled the researcher to collect more data on the phenomena under study. The semi - structured questionnaires were to enable the researcher to collect in-depth information in a flexible environment. This was important in the investigation of the problem (Robson 2002; Hakim 2000; Kombo 2006). Since the study was concerned mainly with variables that could not be directly observed, questionnaires were used. Time constraints and sample size also dictated the use of questionnaires (Kombo 2006).

\subsubsection{Validity}

To enhance the validity of the instruments, the researcher worked with experts and peer - review mechanism to test the instruments. This ensured content, face and construct validity.

\subsubsection{Reliability}

To ensure reliability, the researcher used test -re-test on a sample. The sample for piloting was six businesses representing $10 \%$ of the sample. The sample for piloting did not form part of the research respondents. The outcome of the test-re-test was used to improve the document so that it could capture all responses for the study.

\section{Data Analysis And Discussion}

\subsection{Reliability of the measurement scales}

Cronbach's alpha coefficient was used to measure the reliability of the measurement scales. The scales were found to be acceptable with an alpha coefficient of 0.708 and standardised item alpha coefficient of 0.794. These are minimum acceptable Cronbach's alpha coefficient of 0.7 (Saunders et al. 2009).

\subsection{Background information}

4.2.1 Response rate

The study targeted a total of sixty two micro and small enterprises. Data collection instruments were administered in all the sixty two MSEs out of which fifty seven were returned. This represents a significant 91.93 percent response rate.

\subsection{Types of challenges in MSEs inventory management}

To analyse the kind of challenges facing MSEs, respondents were requested to indicate the extent to which given challenges affected their inventory management. The tables below summarise the information obtained.

\subsubsection{Inventory related costs}

As shown in TABLE 3, 40.3 percent indicated 'very great extent', 24.2 percent 'great extent', 8.1 percent 'very small extent' and 6.5 percent 'small extent'. The implication of this is that 64.5 percent face the challenge of managing inventory related costs. According to Lysons and Farrington (2006) understanding inventory costs is at the core of inventory management and control. 
TABLE 3 Inventory related costs

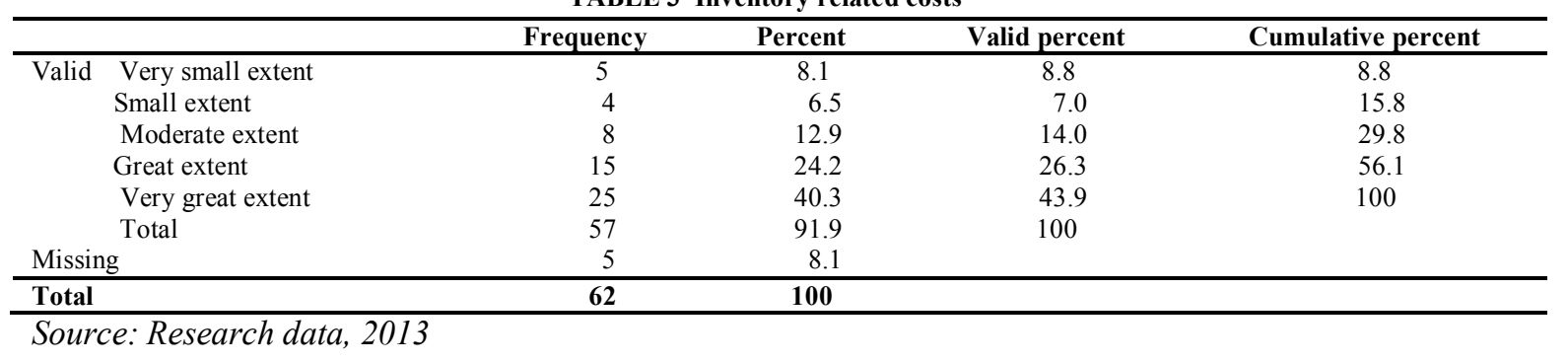

\subsubsection{Correlation analysis}

Correlation analysis was used to test the perceived relationship between inventory costs and inventory management as shown in the TABLE 4 . The analysis yielded a correlation coefficient of -0.498 which was found to be significant at $5 \%$ significance level $(\mathrm{p}$ - value $=0.003)$ which is less than 0.05 . This reveals a strong correlation between variables. This means that inventory cost is a major challenge in inventory management.

TABLE 4: Correlation analysis Symmetric Measures

\begin{tabular}{|c|c|c|c|c|c|}
\hline & & Value & Asymp. Std. Error ${ }^{\mathrm{a}}$ & Approx. $\mathrm{T}^{\mathrm{b}}$ & Approx. Sig. \\
\hline \multirow[t]{3}{*}{ Nominal by Nominal } & Phi & .498 & & & .003 \\
\hline & Cramer's V & .498 & & & .003 \\
\hline & Contingency Coefficient & .445 & & & .003 \\
\hline Interval by Interval & Pearson's R & -.405 & .155 & -3.284 & $.002^{\mathrm{c}}$ \\
\hline Ordinal by Ordinal & Spearman Correlation & -.416 & .145 & -3.396 & $.001^{\mathrm{c}}$ \\
\hline $\mathrm{N}$ of Valid Cases & & 57 & & & \\
\hline
\end{tabular}

a. Not assuming the null hypothesis.

b. Using the asymptotic standard error assuming the null hypothesis.

c. Based on normal approximation.

\subsubsection{Demand variability}

To establish whether demand variability was a challenge, the study asked the respondents the extent to which demand variability was a challenge to the way they manage inventory. TABLE 5 summarises the information obtained. A large number of respondents, 80.6 percent, showed that demand variability was a challenge. 12.9 percent indicated 'great extent' and 67.7 percent showed 'very great extent'. A total of 11.3 percent showed that demand variability was moderately and to a small extent a challenge. This information supports Jemai and Karaesmen (2005), Chopra et al.(2007) and Bejaafar et al. (2005) claim that higher demand variability is associated with deterioration in performance.

TABLE 5: Demand variability

\begin{tabular}{|c|c|c|c|c|}
\hline & Frequency & Percent & Valid percent & Cumulative percent \\
\hline Valid Very small extent & 0 & 0 & 0 & 0 \\
\hline Small extent & 3 & 4.8 & 5.3 & 5.3 \\
\hline Moderate extent & 4 & 6.5 & 17.0 & 12.3 \\
\hline Great extent & 8 & 12.9 & 14.0 & 26.3 \\
\hline Very great extent & 42 & 67.7 & 73.7 & 100 \\
\hline Total & 57 & 91.9 & 100 & \\
\hline Missing & 5 & 8.1 & & \\
\hline Total & 62 & 100 & & \\
\hline
\end{tabular}

Source: Research data, 2013

\subsubsection{Correlation analysis}

Correlation analysis was used to test the perceived relationship between demand variability and inventory management as shown in the TABLE 6 . The analysis yielded a correlation coefficient of -0.673 which was found to be significant at $5 \%$ significance level $(\mathrm{p}$ - value $=0.000)$ which is less than 0.05 . This reveals a very strong correlation between variables. This means that demand variability is a major challenge in inventory management. 
TABLE 6: Demand Correlation analysis

\begin{tabular}{|c|c|c|c|c|c|}
\hline \multicolumn{6}{|c|}{ Symmetric Measures } \\
\hline & & Value & Asymp. Std. Error ${ }^{\mathrm{a}}$ & Approx. $\mathrm{T}^{\mathrm{b}}$ & Approx. Sig. \\
\hline \multirow[t]{3}{*}{ Nominal by Nominal } & Phi & -.673 & & & .000 \\
\hline & Cramer's V & -.673 & & & .000 \\
\hline & Contingency Coefficient & -.558 & & & .000 \\
\hline Interval by Interval & Pearson's R & -.617 & .096 & 5.817 & $.000^{\circ}$ \\
\hline Ordinal by Ordinal & Spearman Correlation & -.559 & .089 & 4.998 & $.000^{\circ}$ \\
\hline $\mathrm{N}$ of Valid Cases & & 57 & & & \\
\hline
\end{tabular}

a. Not assuming the null hypothesis.

b. Using the asymptotic standard error assuming the null hypothesis.

c. Based on normal approximation.

\subsubsection{Information sharing}

Most respondents (27.4 percent) thought that information sharing was a challenge to a moderate extent while 25.8 and 22.6 percent showed that it was to a very great extent and great respectively. It is evident (TABLE 7) that information sharing among channel members could be a challenge. Harland et al. (2007), Chen et al. (2001) and Hamisi (2010) concurs that timely and accurate information sharing helps to shape demand patterns, orders, inventory levels and prices. Inaccurate and incomplete information sharing is a limitation to enterprises.

Table 7: Inadequate information sharing

\begin{tabular}{llcccc}
\hline & Frequency & Percent & Valid percent & Cumulative percent \\
\hline Valid & Very small extent & 3 & 4.8 & 5.3 & 12.3 \\
& Small extent & 7 & 11.3 & 29.8 & 17.5 \\
Moderate extent & 17 & 27.4 & 24.6 & 28.1 \\
Great extent & 14 & 22.6 & 100 & 100 \\
Very great extent & 16 & 25.8 & 91.9 & \\
Total & 57 & 8.1 & & \\
Missing & 5 & $\mathbf{1 0 0}$ & \\
\hline Total & $\mathbf{6 2}$ & &
\end{tabular}

Source: Research data, 2013

\subsubsection{Correlation analysis}

Correlation analysis was used to test the perceived relationship between information sharing and inventory management as shown in the TABLE 8. The analysis yielded a correlation coefficient of -0.615 which was found to be significant at $5 \%$ significance level $(p$ - value $=0.000)$ which is less than 0.05 . This reveals a very strong correlation between variables. This means that information sharing is a major challenge in inventory management

TABLE 8: Information sharing correlation

\begin{tabular}{llrrr}
\hline & & Symmetric Measures & & \\
& & Value & Asymp. Std. Error & Approx. T $^{\mathrm{b}}$ \\
& & -.615 & Approx. Sig. $^{\mathrm{a}}$ \\
Nominal by Nominal & Phi & -.615 & .000 \\
& Cramer's V & -.524 & .000 \\
Interval by Interval & Contingency Coefficient & -.469 & .000 \\
Ordinal by Ordinal & Pearson's R & -.559 & .060 & 3.943 \\
N of Valid Cases & Spearman Correlation & 57 & .070 & 5.001 \\
\hline
\end{tabular}

a. Not assuming the null hypothesis.

b. Using the asymptotic standard error assuming the null hypothesis.

c. Based on normal approximation.

\subsubsection{Setting stock levels}

The respondents showed that determining stock levels in their businesses was difficult (TABLE 9). A total of 82.3 percent indicated 'moderate', 'great' and 'very great extent'. Only 9.7 percent chose 'small extent'. The implication is that setting appropriate levels of stock is a challenge facing MSEs. Businesses accumulate excess inventory when demand is unpredictable because they want to maintain high customer service ( Kot et al.2011). 
TABLE 9: Setting stock levels

\begin{tabular}{llcccc}
\hline & Frequency & Percent & Valid percent & Cumulative percent \\
\hline Valid & Very small extent & 0 & 0 & 0 & 0 \\
& Small extent & 6 & 9.7 & 10.5 & 10.5 \\
& Moderate extent & 13 & 21.0 & 22.8 & 33.3 \\
& Great extent & 20 & 32.3 & 35.1 & 68.4 \\
& Very great extent & 18 & 29 & 31.6 & 100 \\
& Total & 57 & 91.9 & 100 & \\
Missing & 5 & 8.1 & & \\
\hline Total & $\mathbf{6 2}$ & $\mathbf{1 0 0}$ & &
\end{tabular}

Source: Research data, 2013

\subsubsection{Correlation analysis}

Correlation analysis was used to test the perceived relationship between stock setting and inventory management as shown in the TABLE 10.The analysis yielded a correlation coefficient of -0.394 which was found to be significant at $5 \%$ significance level $(\mathrm{p}$ - value $=0.031)$ which is more than 0.05 . This reveals a relationship which might have occurred by chance. This means that generalising the finding might be statistically incorrect.

TABLE 10: Correlation analysis

\begin{tabular}{|c|c|c|c|c|c|}
\hline \multicolumn{6}{|c|}{ Symmetric Measures } \\
\hline & & Value & Asymp. Std. Error ${ }^{\mathrm{a}}$ & Approx. $\mathrm{T}^{\mathrm{b}}$ & Approx. Sig. \\
\hline \multirow[t]{3}{*}{ Nominal by Nominal } & Phi & -.394 & & & .031 \\
\hline & Cramer's V & -.394 & & & .031 \\
\hline & Contingency Coefficient & -.367 & & & .031 \\
\hline Interval by Interval & Pearson's R & -.326 & .121 & 2.557 & $.013^{\mathrm{c}}$ \\
\hline Ordinal by Ordinal & Spearman Correlation & -.353 & .118 & 2.794 & $.007^{\mathrm{c}}$ \\
\hline $\mathrm{N}$ of Valid Cases & & 57 & & & \\
\hline
\end{tabular}

a. Not assuming the null hypothesis.

b. Using the asymptotic standard error assuming the null hypothesis.

c. Based on normal approximation.

\subsubsection{Other challenges}

To ascertain if there were other challenges facing MSEs in the management of inventory, the study requested the respondents to state whether they faced other challenges. The results obtained were: 35.5 percent faced material handling challenges, 30.6 percent experienced dead stocks and 16.1 percent had lead time challenges. A partly 9.7percent said they experienced pilferage of stock items. The results mean that material handling and excess stock due to poor forecasts are also challenges that businesses face in managing stock.

\subsubsection{Demand variability}

\subsubsection{DISCUSSIONS}

The study revealed that there exist a strong negative relationship between demand variability and inventory management (TABLE 5). This shows that MSEs which experience high demand variability have severe challenges of managing stock in their businesses. The respondents showed that the major causes of demand variability include: promotions, prices, seasonality and stock outs. The research also established that MSEs had difficulty in forecasting accurately. According to Jemai and Karaesmen (2005) and Benjaafar et al. (2005) higher demand variability is associated with deterioration in performance which is characterised by higher inventory levels and higher inventory costs.

\subsubsection{Inadequate information sharing}

The study established an association between inadequate information sharing and inventory management (-.615 and p-value less than 0.001) as shown in TABLE 8. The implication is that inadequate information sharing is a limitation. This supports Chopra et al. (2007) and Chen et al. (2000) argument that information sharing results in inventory reductions because of reduced unpredictability thus reduced costs. Although 75.8 percent of the respondents stated that they shared information among the supply chain members, the accuracy and reliability of the information was low. On a likert scale, 45.6 percent indicated that they were slightly confident in the information shared whereas 12.3 percent showed they were confident. Only 8.8 and 4.8 percent stated that they were quite and very confident respectively. In addition, the information shared does little 
to help in management of stock since majority showed that they shared information relating to promotions, lead times and sales history.

\subsubsection{Inventory costs}

The study also revealed that there exists a relationship between inventory related costs and inventory management. Inventory costs and inventory management have a statistically significant negative correlation (0.494 and a p-value $<0.05$ ) as shown in TABLE 4. Majority of the respondents agreed that inventory costs such as buying, transportation, storage, maintenance and handling costs are a challenge to their businesses. This is in line with Hendricks and Singhal (2005) insistence that most obvious inventory costs in businesses include storage costs, capital costs and buying costs. Seventy nine percent of the respondents could not assess the costs appropriately. Lysons and Farrington (2006) stated that it is difficult to determine the costs of sock outs.

\subsubsection{Stock levels}

The study sought to find out whether setting stock levels was a challenge in inventory management. It was established that there is a statistically insignificant association between the two variables at -0.394 with $p$ value $=0.31$. The relationship might be by chance. However, the study established that 67.7 percent of the respondents had set minimum stock level while 24.2 percent had not. This shows an effort to match stock with customer requirement. As argued by Sople (2010) the key to inventory management is striking a balance between carrying inventory and meeting customer requirements. According to this study, some of the factors which influence stock levels in micro and small enterprises include lead time, demand patterns, inventory costs and supplier information.

\section{Conclusions}

The general objective of the study was to evaluate the challenges MSEs face in the management of inventory. The results obtained strongly suggest that there is a strong relationship among the three out of four variables. According to the obtained results, there is no doubt that demand variability plays a role in inventory management. Variability of demand is mainly caused by promotions, seasonality and prices. The higher the demand variability, the more complex it is to manage the inventory. Furthermore, demand forecasts are of little help to the businesses. The study also concludes that inadequate information sharing has a strong negative correlation with inventory management. The information shared by the MSEs is incomplete, inadequate and unreliable. This complicates the levels of stock and the costs of inventory. This is closely related to the challenge of inventory costs. It is evident that MSEs incur costs of storage, transportation, handling and buying of stock items. The study established a strong negative correlation between inventory costs and inventory management. However, the study found an association between stock checking and inventory management at statistically significant level above 0.05 . It implies that the association could be by chance. This study will provide evidence of challenges facing MSE s since $40-60 \%$ of their money is tied up in stock. It will also contribute empirical knowledge to the field of inventory management in businesses.

\section{References}

[1]. Alade, J., Sharma, D., \& Sharma, H. (2004). Role of supply chain management decisions in effective inventory control. Journal of Academy of Business and Economics Publisher.Retrieved from http://www.ismsv.groupsite.com/discussion/ topic/show/144758/

[2]. Baily, P., Farmer, D., Jessop, D., \& Jones, D. (2005). Purchasing principles and management. ( $9^{\text {th }}$ ed.). London: Prentice Hall.

[3]. Balakrishman, R., Linsmeier, J., \& Venkatachalan, M. (1996). Financial benefits from JIT adoption : effects of customer concentration and cost structure. Accounting Review 71 (183 - 205). Retrived from http://www.jsto.org/stable/248445/

[4]. Benjaafar, S., Cooper, W. L., \& Kim, S. (2005). Benefits of pooling in production-inventory systems. Management Science 51, 4, p 550-556.

[5]. Bowen, M., Morara, M., \& Mureithi, S. (2009) Management of business challenges among SMEin Nairobi- Kenya. KCA Journal of Business Management. 2(1), 2009. Retrived from http://www.ajol.info/index.php/kjbm/article/view File/4408/27917

[6]. Bowersox, D., \& Closs, D. (1996). Logistical management: The integrated supply chain process. New York: McGraw Hill Companies.

[7]. Chandra, B. (2007). Inventory management. New York: Prentice Hall.

[8]. Chandra, C., \& Kumar, J. (2001). Taxonomy of inventory policies for supply chain effectiveness, $129(4), 2001: 3$

[9]. Chapman, S., Ettkin, L.P., \& Helms, M.M. (2000). Do small businesses need supply chain management? IIE Solution, 32 (8):3

[10]. Chase, R., Jacobs, F., \& Aquilano, N. (2004). Operation management for competitive advantage.(11 $1^{\text {th }}$ international edition.) New York: McGraw Hill.

[11]. Chen, F. (2002). Information sharing and supply chain coordination. Working Paper, Graduate School of Business, Columbia University, New York.

[12]. Chen, H., Frank, M., \& Wu, O. (2007). U.S retail and wholesale inventory performance from1981 to 2004 Manufacturing \& Service Operations Management 9, 430- 456.DOI: 10.1287/mosm.1060.0129

[13]. Clodfelter, R. (2003). Retail buying from basics to fashion. ( $2^{\text {nd }}$ ed.). New York: McGraw Hill.

[14]. Chopra, S., Meindl, P., \& Kalra, V. (2007).Supply chain management: strategy, planning and operation. New Delhi: Dorling Kindersley.

[15]. Christopher, M. (2005). Logistics and supply chain management: Creating value - added networks. Harlow: Prentice Hall.

[16]. Chu, H., Cynthia, B., \& McGee, C. (2007). Ghanaian and Kenyan entrepreneurs: A comparative analysis of their motivations, success characteristics and problems. Journal of Developmental Entrepreneurship, 12(3), 295-322.

[17]. Cohen, S. \& Roussel, S. (2005). Strategic supply chain management: The five disciples for top performance, McGraw-Hill. 
[18]. Controllers Report. (2006). Inventory benchmarks. June, available at http://www.ioma.com/issues/CR2006 5/

[19]. Council of Supply Chain management Professionals: "SupplyChain Management/Logistics Management Definitions," available at http://www.cscmp.org/website/definitions.

[20]. Daniels, L., \& Mead, D. (1998). The contribution of small enterprises to household and national income in Kenya. Chicago: University of Chicago.

[21]. David, P., \& Stewart, R. (2007). International Supply Chain Management. New Delhi: Cengage Learning.

[22]. Dobler, W., \& Burt, D. (1996). Purchasing and supply management. (6 $6^{\text {th }}$ ed.) New York: McGraw Hill Companies.

[23]. Fawcett, E., Ellram, M., \& Ogden, J. (2007). Supply chain management: From vision to implementation. Upper Saddle River, New Jersey: Prentice Hall.

[24]. Fisher, M. (1997, March- April). What is the right supply of chain for your product? Havard Business Review,101-16. Retrived from http://www .computingscience.ni/docs/vakken/scm/Fisher.pdf

[25]. Gathumbi, N. (1997). Application of inventory models in drug inventory management: a case of NCC health services, available at http://www.kenya.smetoolkit.org/kenya/en/content/managing-your-inventory/

[26]. Goldratt, E. Theory of Constraints. Available at http://www.goldratt.com/theoryofconstraints.

[27]. Gunasekaran, A., \& Ngai, E. (2004). Information systems in supply chain integration and management. European Journal of Operational Research, 159: 269-295. DOI: $\quad 10.1 .195 .2311$

[28]. Hakim, C. (2002). Research design: successful designs for social and economic research. ( $2^{\text {nd }}$ ed.). London: Routledge.

[29]. Hamisi, S. (2010). Challenges and opportunities of Tanzania's SMEs in adapting supply chain management. African Journal of Business Management, 5(4) 1266-1276.

[30]. Harland, C., Caldwell, N., Powell, P. \& Zheng, J. (2007). Barriers to supply chain information integration: SMEs adrift of ehands, Journal of Operation Management, vol. 25

[31]. Hatten, T.S. (2012). Principles of small business management. (5 ${ }^{\text {th }}$ ed.) New York: South-Western Cengage.

[32]. Hau, L., \& Billington, C. (1992, April). Managing supply chain inventory: Pitfalls and Opportunities. MITSloan Management Review.

[33]. House, B. (2009). Revisiting the micro and small enterprise sector in Kenya. Indiana University.DOI: 10.111J.14780542.2009.00642.X

[34]. Jemai, Z. \& Karaesmen, F. (2005). The influence of demand variability on the performance of a make-to- stock queue, European Journal of Operational Research, 164, 195

[35]. Jessop, D., \& Morrison, A. (1994). Storage and supply materials.London:Pitman Publishing.

[36]. Johnson, F., Leenders, M.R., \& Flynn, A.E. (2011). Purchasing and supply management. (14 ${ }^{\text {th }}$ ed.) New York: MacGraw Hill.

[37]. Kauffmann, C. (2005). Financing SMEs in Africa, Policy Insights No.7. OECD. Retrived from http:// www.oecd.org/dev/insights

[38]. Kombo, K.D., \& Dello, A.A. (2006). Proposal and thesis: An Introduction. Nairobi:Paulines Publication Africa .

[39]. Kot, S., Grondys, K. \& Szopa, R. (2011). Theory of inventory management based on demand forecasting. Polish Journal of Management Studies, vol.3

[40]. Larson, D., \& Halldorsson, A. ( 2004, March). Logistics vs. supply chain management: An international survey. Journal of Supply Chain Management, 17-31.DOI 10.1080/13675560310001619240

[41]. Lysons, K., \& Farringtom, B. (2006). Purchasing and supply chain management. ( $7^{\text {th }}$ ed.) New Jersey: Prentice Hall.

[42]. Makena, L.M.,.(2010) Challenges affecting management of inventory in the central government of Kenya, a case study of police department. Nairobi: (unpublished).

[43]. Mbithi, M., \& Mainga, J. (2006). Doing business in Kenya: Procedures and regulation, opportunities, sources of finance and incentives. Nairobi: United Nations Development Programme.

[44]. Monczka, R., Trent, R., \& Handfield, R. (2002). Purchasing and supply chain management. (2 ${ }^{\text {nd }}$ ed). South-West: Tomson Learning.

[45]. Morgenstern, I. (2007). Introduction theory of inventory control. New England: Markus Zizler.

[46]. Muckstadt, J., \& Sapra, A. (2007). Principles of inventory management. New York: Springer-verlag Publishers.

[47]. Mugenda, O., \& Mugenda, G. (1999). Research methods: qualitative and quantitative approaches. Nairobi: Nairobi Act Press.

[48]. Prasad, S., Tata, J., \& Madan, M. (2005). Build to order supply chains in developed and developing countries. Journal of Operation Management, Vol.23 No.5, 551-568.

[49]. Prasad, S., \& Tata, J. (2010). Microenterprise SCM in developing countries. Journal of Advances in Management Research, Vol.7 (1), 8-11. DOI: 1108/09727981011042838.

[50]. Rajagopalan, S., \& Malhotra, A. (2001). Have US manufacturing inventories really decreased? An empirical study. Manufacturing Service Operations Management (3), 14-24. DOI: 10.1287/msom.3.14.9995

[51]. Republic of Kenya. (1999). National micro and small enterprises baseline survey results. Nairobi: Government Printers.

[52]. Republic of Kenya (2005). Sessinal paper no.2 of 2005, on development of micro and small enterprises for wealth and employment creation for poverty reduction. Nairobi: Government Printers.

[53]. Robinson, R., Logan, J., \& Salem, M. (1986). Strategic versus optional planning in small retail firms. American Journal of Small Businesses, 10 (1) 7 - 16 DOI: 10.1108/026217/0410549611

[54]. Robson, C. (2002). Real world research. (2 $2^{\text {nd }}$ ed.). Oxford: Blackwell.

[55]. Sarmaha, S.P., Acharyaa, D. \& Goyal, S.K. (2005). Buyer vendor coordination models in supply chain management. European Journal of Operational Research, vol. 175,1- 15.

[56]. Saunders, M., Lewis, P., \& Thornhill, A (2009). Research methods for business students. (5 ${ }^{\text {th }}$ ed.) London: Personal Educational Ltd.

[57]. Sople, V.V. (2010). Logistics management. (2 $2^{\text {nd }}$. Ed.). New Delhi: Dorling Kindersley.

[58]. Stock, J., \& Lambert, D. (2001). Strategic logistics management. (4 ${ }^{\text {th }}$ ed.). London: McGraw.

[59]. Tersine, R. (1982). Principle of inventory and material management. $2^{\text {nd }}$ ed. North Holland: McGraw.

[60]. Thiel, D., Hovelaque, V., \& Hoa, T.L. (2009). Impact of inventory inaccuracy on service level quality: A simulation analysis. Retrived from http://www.rennes.inra.fr/smarteng/publications/workingpapers /

[61]. Tomecko, J., \& Dondo, A. (1992). Improving the potential of small scale and informal sector. Nairobi: K- REP and GTZ.

[62]. Walters, D. (1992). Inventory control and management. Chichester, New York: John Wiley and Sons.

[63]. Waweru, C.L., (2010). Effects of inventory levels and stock outs on procurement performance at Kenya Forestry Research Institute.Nairobi: (unpublished)

[64]. Wild, T. (2002). Best practice in inventory management. ( $2^{\text {nd }}$ ed.). Butterworth: Heinemann UK.

[65]. Yin, K. (2003). Case study research: Design and method. ( $3^{\text {rd }}$ ed.). London: Sage.

[66]. Yu, Z., Yan, H. \& Cheng, E. (2001). Benefits of information sharing within supply chain partnerships. Industrial Management and Data System, 101(3),114-119. 